\title{
Terrorist Attacks on Non-Governmental Organizations
}

\author{
Craig S. Stapley \\ Department of Political Science, Kansas State University, Manhattan, Kansas, USA \\ Email: cjstap@ksu.edu
}

Received 2 August 2014; revised 1 September 2014; accepted 30 September 2014

Copyright @ 2014 by author and Scientific Research Publishing Inc.

This work is licensed under the Creative Commons Attribution International License (CC BY). http://creativecommons.org/licenses/by/4.0/

(c) (1) Open Access

\begin{abstract}
Understanding the process by which terrorist groups decide on whom to target would seem to be a process that might lend itself to study and generalization that would be helpful in predicting later attacks. This study hopes to look at the attacks on non-governmental organizations and determine if there is a systematic set of measures that would allow us to determine if terrorist groups do rationally approach target selection in such a way to derive a pattern that would inform future attack avoidance.
\end{abstract}

\section{Keywords}

Terrorism, Targeting, NGO, Non-Governmental Organization, Terrorist

\section{Introduction}

This paper hopes to create and justify the framework as to why terrorist groups might target non-governmental organizations (NGOs) that may then be generalizable to the larger population of terrorist attacks. It will establish the terrorist's targeting rationale. In order to institute this framework, a comprehensive study of attacks on NGOs was carried out. For the purposes of this study, various databases that contained records of these types of attacks were consulted. After consulting the various databases, the central data for this research was compiled. It contains approximately 500 cases of terrorist attacks on NGOs and religious groups from 1970 to 2000.

Determining the actual process by which targets were chosen is a task fraught with intellectual pitfalls. Obviously, it is impossible to know exactly what the terrorist groups were thinking or what emphasis they placed on which targeting parameters to finally arrive at the selected target. However, after careful study of the databases, various patterns emerged. The purpose of this study was not to create empirically testable hypotheses. This is a preliminary study in the field of target selection which focuses on NGOs in particular. While a database is typically used to statistically test hypotheses, the database compiled for this study has a primary purpose of provid- 
ing a large pool of like phenomenon through which patterns could be divined. As such, readers should not be disappointed when statistical testing is not conducted for each of the framework parameters.

The main source materials used are the START's Global Terrorism Database which has been compiled primarily from news publications worldwide and is the intellectual descendant of the RAND database, the St. Andrews Database, and the MIPT databases. This database includes information as to number of deaths; number of injuries; the nationality(s) of the target; the alleged perpetrator(s); the incident date; the tactics used; the country that the attack occurred in; the source of the information; and finally a brief summary of the attack. These databases include domestic and international terrorist incidents which occurred from 1968 to 2004. Information used as secondary sources include the U.S. government reports Political Violence Against Americans, Significant Incidents of Political Violence Against Americans, and the Patterns of Global Terrorism 2000-2002, which are government reports of violence against Americans. All of these sources are in the public domain and readily obtainable by the general public.

\section{The Framework: Why NGOs Become the Targets of Terrorists}

This research assumes that terrorist groups are rationally constructing targeting imperatives for both strategic and/or ideological reasons as well as tactical reasons. Drake (1998) creates a targeting funnel with the total available targeting options at the top or widest point of the funnel. At each level the option is constrained and the available targets are diminished. In the end the final target option has been filtered first by ideology; whether the target is ideologically in harmony with the group's goals, then by strategy; whether the means by which the attack is carried out is productive to the goals of the groups, then by tactics; whether the attack is feasible and survivable for the group. All of these refinements affect the final target selection. It is also understood that the attack itself will bring a reaction which will then bring about a change in the targeting criterion for the next attack.

The framework advanced by this research expands on Drake's targeting process due to the fact that it contains ideological, strategic and tactical reasons that terrorist groups might target non-governmental organizations. It is an expansion on Drake's targeting refinement process in that it identifies five terrorist targeting imperatives relating to non-governmental organizations specifically. These imperatives are first, that terrorist groups perceive a real or imagined association between the non-governmental organization and a political entity (whether state or non-state); second, that the NGO, or its agents, engage in political activities that bring them into conflict with the terrorist group; third, that the non-governmental organization either actively or solely by virtue of being what it is represents a threat to the social, cultural, or religious environment considered important to the terrorist organization; fourth, that NGOs become competitors for resources that the terrorists desire; and fifth, that NGOs are relatively soft in terms of ease of attack, and as such, desirable targets.

\subsection{Association}

The first targeting imperative that might explain why terrorists target non-governmental organizations is that terrorist organizations may perceive that an NGO has an association with a political entity. It is important to point out that this association need not necessarily exist in real life, only that the terrorist group perceives that it exists. A terrorist group may target an American business based on the fact that it is American and as such has political ties to the United States. It may not matter that the business is multinational as long as the terrorists associate the business with the United States. This association may be even more tenuous when looking at religious or humanitarian NGOs. The fact that the NGO may be based in the United States creates a relationship to the United States. American students traveling outside the United States have understood this association for years. Occasionally, American students will sew a Canadian flag onto a backpack in order to avoid ill will that may be associated with Americans. Hoffman noted this kind of terrorist threat: "Clearly, then, a variety of American citizens traveling, living and working overseas-but who have no ostensible or official connection with the U.S. government-are indeed already firmly in the terrorists' cross-hairs” (Hoffman, 2001: 10).

Shaffert captured this targeting imperative when he noted that a terrorist victim is, "representative of a target group that is strategically involved in the terrorist's political goals" (Shaffert, 1992: 44). Shaffert cited the 1985 murder of a U.S., Serviceman on TWA's flight 847. He noted that the target was not necessarily the serviceman, but "the American public who observed the atrocity through the international media" (Shaffert, 1992). As long as an association can be established linking the immediate target with the larger audience, then the targeting selection is justified in the mind of the terrorists. Indeed, perhaps the more "innocent" the better as an innocent 
victim might garner more of the attention of the larger target audience.

In order to demonstrate this associational parameter, cases contained in the database will be introduced. Attacks against the Church of Jesus Christ of Latter-Day Saints (also referred to as the LDS Church) in Latin America prove to be illustrative. Latin America during the 1980's was rife with terrorism and political violence. During that time and in that area, there were 211 attacks against NGOs or religious organizations recorded in the database. By far the majority of the attacks (66.8\% or 143 incidents) targeted the people or property of the Church of Jesus Christ of Latter-Day Saints. The LDS Church is an international church based in Salt Lake City, Utah in the United States. The church is expressly apolitical, going to great lengths to proclaim itself politically neutral. Indeed, instruction to general authorities of the church as well as local leadership expressly emphasizes that political activities for or against any given issue by church officers in their official church capacity will not be tolerated, nor will the church take a political stand on political issues except in cases of moral questions such as the abortion issue or legalization of gambling. If this is the case, then the question must be asked as to why the majority of the terrorist attacks in Latin America targeted the LDS Church. This research theorizes that the LDS Church was targeted due to the perceived association by terrorists groups between the church and the United States rather than for political activities engaged in by the church or its officers.

Cases in the database help to explain some of the attacks on the LDS Church. Twenty-six percent of the attacks on the LDS Church were accompanied by either literature in the form of pamphlets or slogans painted on buildings proclaiming the attack as an attack not necessarily on the church but one on the United States. Interviews of church officials who were present after some of the attacks confirm that in most of the cases, anti-U.S. literature or slogans were left at the sites (Interview Results).

Examples of this type of attack include 1983 attacks executed by the National Liberation Army (ELN) of Columbia. In those attacks, the ELN conducted dynamite attacks on entities associated with the United States in Bacaramanga. The entities were the Columbo-American Cultural Institute, the International Bank of Columbia (an affiliate of Citibank), and the Church of Jesus Christ of Latter-Day Saints (Database). A series of incendiary attacks in 1985 in Chile had pamphlets left at the scene proclaiming, "Yankees get out of Easter Island" (Database). A slogan painted on a wall after a 1987 molotov cocktail attack in Santiago, Chile stated, "Out of the common people's territories Yankee invaders" (Database). A 1989 attack conducted by the Tupac Amaru group warned "Mormons and DEA agents" to leave the upper Huallaga Valley (Database). The terrorist groups associated the LDS Church with the United States and launched attacks on that basis alone.

Indeed, attacks seem to increase based on United States foreign policy. If the attacks on the LDS Church in Latin America are studied, it seems that attacks increased after significant U.S. foreign policy action. Terrorist attacks on the LDS Church prior to 1983 are relatively rare. However, after 1983, attacks on the LDS Church significantly increase. It can be theorized that the U.S. invasion of Grenada as well as U.S. activities with the Contras in Nicaragua were behind the increased attacks which occurred in 1984-89. Similarly, attacks on the LDS Church increased significantly after the U.S. invasion of Panama.

Statistical analysis of the database tends to confirm that the terrorists increased attacks on the LDS Church after the Panama invasion. Prior to the Panama invasion, attacks on the LDS Church made up 54.8 percent of all terrorist attacks in Latin America. After the Panama invasion, attacks on the LDS Church made up 74.4 percent of all terrorist attacks in Latin America. The LDS Church engaged in no significant changes in policy or doctrine during that period of time. It can thus be theorized that the increase was due to some other reason.

To help derive causation for the increased attacks, the evidence of the attacks themselves must be studied. In the two years following the U.S. invasion of Panama in 1989, 26.5 percent of the LDS Church attack sites in Latin America had evidence left by the attackers which contained references to the recent U.S. invasion (Database). In these cases, the terrorists gave voice to why the attacks were occurring. In their own words, the attacks were meant as a means of conveying a message to the U.S. government, "U.S. out of Panama" (Database).

Examples of this type of attack include the 1989 assassination of two LDS missionaries. In that attack, the Zarate Wilka Armed Forces of Liberation (FAL), sent a letter to the local newspaper denouncing, "Yankee invaders and their lackeys". The attack coincided with the arrival of U.S. military personnel in Potosi who would be constructing a new airport (Database). Six attacks on LDS buildings following the U.S. invasion of Panama claimed the attacks were in retaliation for the invasion (Database). Similar attacks were conducted against LDS buildings following the attendance of President Bush at the Cartagena Drug Summit in 1990, the first Gulf War, the invasion of Haiti, and the deployment of U.S. Army Engineers to Columbia in 1994 (Database).

Certainly, recent events in Iraq seem to bolster the theory that at times, terrorists select targets simply based 
on the nationality of the victim and that the victim's actual connection to the government of his or her home nation irrelevant. If, in fact Jenkins supposition is correct, that terrorists are conducting activities for a larger audience in an attempt to use the media attention garnered by the act to influence the larger population, then the more "innocent" the victim(s), the better (Jenkins, 1981). The graphic representations of an "innocent" journalist or truck driver being beheaded to the cries of "God is great", make much more of an impact on a watching audience than the execution of a captured soldier or government official.

This associational danger seems to be acknowledged by the U.S. government. After the September 11th attacks, embassy officials told one U.S. expatriate "to refrain from doing anything that would label him American" (Tryggestad, 2001). This is especially true since September 11th and the call to attack Americans wherever they are located.

An association need not be solely be with a government entity. Indeed, if an NGO is associated with a nonstate entity such as the United Nations, any assumptions made about the general organization may be transferred to the NGO associated with that organization. Eighty four percent of all attacks on NGOs associated with the United Nations (UN) or the Red Cross occurred in the time period following the U.S. and coalition invasion of Iraq in the First Gulf War. Before that time, attacks on NGOs associated with the UN or Red Cross made up three point eight percent of all terrorist attacks. After the Gulf War, attacks on UN or Red Cross NGOs made up 17.9 percent of all terrorist attacks. Certainly, by their own propaganda, many fundamentalist terrorist groups have begun to associate the Red Cross and the United Nations Security Council with Western domination.

Some NGOs rely on the real association that exists with government entities. Many NGOs rely on government funding in order to accomplish their goals. Clearly, as Edwards and Hulme (1996) documented, many NGOs are beholden to governments for their existence. The question must then be raised, "can an NGO really be non-governmental if a government is a stakeholder in the NGO?" Some NGOs rely on governments for security as well. Additionally, governments provide NGOs with legitimacy and ideological capital with which to carry out missions. In these cases, an NGO may reap positive benefits from a government association, but the negative aspects cannot be ignored.

As stated at the beginning of this research, it would not be the purpose of the database to construct statistical tests with which to measure the ability of the framework to predict the targeting priorities of terrorist groups. However, 15.38 percent or 68 incidents had explicit statements by the terrorist groups that the attacks were committed on targets associated with a political entity. Additionally, incidents where details allow the inference of the targeting strategies allow the researcher to determine that an additional 196 incidents or 59.7 percent of terrorist attacks have an associational component.

\subsection{Political Activity}

It must be noted that terrorism is a fundamentally political phenomenon (Abrahms, 2008). As such, political motives must help guide a terrorist group in selecting targets. Hence, the second way that NGOs might be brought into the crosshairs of terrorist groups relates to activities that an NGO might be engaged in that are in conflict politically with the terrorist group. The difficulty arises in actually defining what political activity is. Some definitions focus on the mechanisms of government- the apparatus of state. As such, terrorists might target NGOs in order to gain control of the mechanisms of government.

While many NGOs are apolitical in the way they organize and carry out their various missions, many are not. A group engaged in political struggle might be moved into the "legitimate" target category. It is important to note that political activity might bring about terrorist attacks by both traditional non-state terrorists as well as state sponsored terrorism.

The general political activity category can be divided into two general sub-types. The first is traditional political activity, which might be considered work for or against governments or programs by an NGO. The second type is much more nebulous. This political activity is any activity, which may not be political in nature, but one that subverts the terrorists program for control. Put another way, the first type is traditional political activity that goes against the terrorist group's ideological or strategic plans. The second type is any activity that goes against the terrorist group's strategic or tactical plans. The first type is at the top of the funnel; the second is farther down.

Overt political activities will be considered first. NGOs may engage in the traditional political process. This may put them at political odds with terrorists. For example, an NGO, which chooses to promote a free market, 
democratic form of government, may find itself afoul of a Marxist terrorist group. Once again, the database is illustrative for this concept. Seven point six percent or 34 terrorist incidents out of all terrorist attacks were on targets engaged in overt political activities (Database). Certainly the definition of overt political activity is open to interpretation. This study defines overt political activity as an NGO working for or against one political entity that is engaged in political struggle. For example, an NGO working in a country engaged in civil war, which chooses to support, either by material or endorsement, one of the combatant sides would be considered to be engaged in overt political activity. This type of situation was cited by Randolph Martin when describing the threats to NGOs. Adding to the threat level is "the erosion of the accepted neutrality of aid groups, who are seen by some belligerents as partisan, interventionist and generally an undesirable presence” (Martin, 1999).

Perhaps a good example of this type of activity is another religious organization, the Roman Catholic Church. Compared to the first example, the Catholic Church is vastly larger in terms of total membership as well as demographic proportion of the population. This is especially true in Latin America where much of the terrorist activity took place until the mid-1990s. By virtue of its population and history in Latin America, the Catholic Church has become part of the Latin culture and society. However, of the total number of terrorist attacks in Latin America, 11.4 percent were against the agents or property of the Catholic Church. All told, 78.2 percent of all terrorist attacks against NGOs in Latin America were against the LDS and Catholic Churches. One of the factors, which set the Catholic Church apart from the LDS Church, is the fact that the Catholic Church and or its agents have been willing to engage in political struggle.

In order to understand the justification that terrorists might use to bring the Catholic Church into the crosshairs, it is important to understand the history and policies pursued by those of the Catholic Church. Initially, the Catholic Church was seen as a bastion of conservatism, oftentimes providing legitimacy to governments. Anciently, the Church was the means by which kings could claim divine right, and thus, justify any action; good or bad. Claiber notes that, "the church legitimated the colonial order". He goes on to point out that, "The church was the only colonial corporation that could confer religious legitimacy on persons and institutions, and that legitimacy in turn gave those persons a privileged status” (Claibur, 1998: 4). In modernity, the support of the church provided similar legitimacy.

In recognizing the legitimizing power of the church, terrorist groups seek to harness that power for themselves and against those they are fighting. In 1977, two French nuns were kidnapped in Buenos Aires, and communiqués by the Montonero guerrillas demanded that the Catholic Church repudiate the military government of Argentina (Database). Clearly, the terrorists felt that the support given by the Catholic Church to the military government was integral to legitimizing the government in the eyes of the general population. The kidnapping was meant as a means of forcing the church to withdrawal support for the government, thus reducing the government's power.

In the case of Latin America, the Catholic Church exercised traditional authority. Over time, they had exercised power, and therefore were looked to as a legitimizing influence. For example, the Catholic Church played a legitimizing role with rightist governments. Ofreneo notes that the Catholic Church was willing to support rightist governments in order to protect its preeminent religious position within the state (Ofreneo, 2004). Indeed, he cites the willingness of the Catholic Church to condone the actions of the Marcos government in the Philippines to protect its tax-exempt status. There also seemed to be an ideological conflict between the Catholic Church and leftist governments. Marxist governments stressed the concepts of solidarity and class struggle over religion. Indeed, Marx's labeling of religion as the "opiate of the masses" was seen as a direct attack on the power of the church (Marx, 1978: 53-54). As a result, many leftist groups and governments found themselves at opposition to the church.

Finally, the Catholic Church provided means by which the powerful, conservative, upper classes could remain in power over those in the lower classes. This is the argument proposed by Phillip Berryman, "the war in Central America is a religious and theological war, a struggle between gods situated on both sides of the conflict”. It is between the "powerful (who) seek to prevent God's realm from arriving... (and) the poor (who) have discovered that "the God of Western Christian Society was not the God of Jesus, but rather an idol of the Empire” (Berryman, 1994: 206).

That is not to say that the church remained the central legitimizing influence. Indeed, as the concepts of democracy and human rights began to flourish and the church did not respond, it began to lose this divine legitimizing authority. Indeed, "the church came seriously close to finding itself marginalized in the wake of these great changes, which were sweeping over Latin America” (Claibur, 1998: 5). 
In order to bring the church back to the center of its people's lives and avoid marginalization, the church changed. "It ceased to be a bulwark of the established order and turned into a force for social change". This change did not occur quickly. However, by 1968, and through such conventions at the Second Vatican Council and the Episcopal Conference in Medellin, the Catholic Church had transformed itself into an organization which championed democracy, social and human rights (Claibur, 1998: 5). Indeed, this change has come to be known as "liberation theology". In this way, the Catholic Church moved from conservative to liberal, which was to have a profound effect on its status as a terrorist target. The Catholic Church changed the traditional stance where it had lent its legitimizing power to rightist governments and began to legitimize leftist or democratic governments.

Under the system that saw the Catholic Church as the conservator of upper class power and right-leaning dictatorships, it is not inconceivable that revolutionary terrorist groups might have targeted the Catholics as a way of attacking the legitimacy of the regime they were trying to undermine. Marxist groups might have targeted the church for ideological reasons. But in the end, it was the church after Medellin that entered the gun sights of terrorists. The Catholic Church changed the traditional stance where it had lent its legitimizing power to rightist government and began to legitimize leftist or democratic governments. This change on the political spectrum was significant in that revolutionary terrorist who had previously looked at the Catholic Church as an enemy now saw it as a potential ally. However, regimes, which had seen the church as an ally, now saw a potent tool for building legitimacy eroding it.

Attacks on Catholic personnel in general did come about. However, attacks on specific agents who took the counsel of Medellin to heart and who became activists for human rights and social change now found themselves in danger. In 1998, Bishop Juan Gerardi was, "beaten to death two days after presenting, as coordinator of the Archbishop's Human Rights Office, a report on human rights violations and crimes committed during the 36 year domestic conflict that concluded in 1996" (Database).

In some cases, the political activity is the actual advocacy of one side or another in a political struggle. In 1997, A Canadian priest was killed while officiating in a Mass, apparently in retaliation for helping Tutsis escape the massacres in 1994 (Database). Father Timothy Majic was sent a letter bomb after contributing to a Croatian language newspaper, which advocated a free Croatia in 1979. In 1987, Father Guido Peeters, a parish priest of the worker's district of La Legua, one of the poorer slums in Santiago, was kidnapped, stripped naked, beaten, threatened and photographed. His parish has been the site of frequent demonstrations against Pinochet's government. Father Peeters' parish was also fired upon in 1985. Father Stanley Rother was executed by people dressed in the uniform of the Guatemalan Army after sending letters to the government documenting atrocities conducted by the army on people in the village in which he worked. Father Rother, in an interview with the Los Angeles Times, stated that he was on a list of people that would be killed. The choosing of one side in a civil war (or even a genocide), led these priests to be targeted by the other side.

The political action need not be so clear. Neither need the choosing of sides be involved. In some cases, the political action could be involvement as an intermediary. In 2000, the National Liberation Army of Colombia (ELN) kidnapped soon-to-be ordained Jesuit priest, Alejandro Matos Castro as he was trying to negotiate the release of Revolutionary Armed Forces of Colombia (FARC) captives (Database). The Ecuadorian Bishops Conference was letter-bombed in 1998 after they took on the task of preparing the census, which, in turn, would determine who got subsidies. In 2002, the parish priest of Nuestra Senora de la Asuncion was killed. He had been on the President of Florencia's Peace Board and had "helped with efforts to release hostages and to avoid killings by both guerrillas and paramilitary groups” (Database). Also in 2002, the home of Caracas Archbishop Ignacio Velasco, who was advocating talks between the Chavez government and the opposition, was bombed. In these cases, involvement in nonpartisan political endeavors brought agents of the Catholic Church into the gunsights of terrorists.

Murdie et al. (2014) also looked at terrorist targeting of nongovernmental organizations engaged in overt political activities. They found that terrorist groups targeted nongovernmental organizations engaged in human rights advocacy. When they compared human rights advocacy groups to non-advocacy groups they found that an increase in non-advocacy groups did not increase the likelihood of terrorist attacks on these NGOs, but the increase in human rights advocacy groups did, thus showing quantitatively that terrorists target NGOs engaged in overt political activity.

The second type of political targeting is the result of activities which may not seem be political in nature. However, a return to the competing definitions of politics may be useful. Harold Laswell's (1936) definition of 
politics being "who gets what, where, when, and how", describes activities that are much less traditionally "political” in nature. Indeed, NGOs may be engaged in activities, which may seem expressly non-political, such as humanitarian aid or human rights promotion. However, those activities may bring an NGO into political conflict nonetheless. An explication of this principle may be helpful. Certainly much of what a terrorist group is concerned with is political power. Indeed, it is one of the definitional characteristics of a terrorist group. Terrorist groups attempt to change power dynamics through the threat of violence. Any other phenomenon that has the ability to change the power dynamics, or even reinforce the old dynamic, can bring itself into conflict with a terrorist organization which is trying to do the same in an opposite direction.

One of the methods that insurrectionist terrorists use to gain political power is the subversion of governmental power. One of the chief means by which governments maintain power, especially in difficult times, is through legitimacy. This aspect of political legitimacy goes directly to the heart of terrorist goals. If the terrorist group can convince the general population that the current regime type is not able to handle the current situation, or that it is not the, "most appropriate or proper ones for the society", then it has seriously weakened the government (Lipset, 1959: 86). A terrorist group might reduce government power by reducing the legitimacy the citizenry feel the government possesses. If a terrorist group can make the citizenry feel that the government cannot maintain order or basic rights, then this can help to reduce the legitimacy of the government. An NGO working to establish peace and prosperity thus might work against the aims of a terrorist group bent on de-legitimizing government. Hence, the NGO becomes a target for the terrorist group.

Political power can also be put in terms of influence. It can be theorized that terrorist groups might target NGOs that threaten the terrorists' influence with a group of people. It can be seen that NGOs have also been targeted because of a struggle for influence over non-state ethnic entities. The power of an ethnic group or subgroup to influence its members cannot be overstated. Thus, when NGOs work with ethnic groups, tribes and other sub-state actors, they place themselves at risk due to competition for the influence of that group. For example, in 1999, the Revolutionary Armed Forces of Columbia (FARC) kidnapped and later killed three Americans who had been working for an NGO dedicated to working with the U'wa, a tribal community that had resisted outside interference or development (Database). Similar attacks by FARC have targeted the NGO Maya Foundation as well as other groups working with indigenous peoples. The terrorist group Tupac Amaru has attacked groups in Peru working with Amazon tribes as well as indigenous peoples of the Andes (Database).

NGOs could put themselves at risk if they become the agent of stability. Starvation, famine and terror have been used effectively by dictators in order to keep control of potentially restive populations. This concept is captured in the historical foundations of terrorism. As mentioned previously, the very word terrorism is derived from the French state sponsored program of inducing fear among the population in order to control it (Laqueur, 2001). Stalin's programs against the peasant populations of Russia are another good example of this concept. Controlling the food supply or mechanisms for basic sustenance guarantees the ability to control the population that depends on it to survive. Thus, NGOs dedicated to humanitarian aid and simply feeding starving people may find themselves at odds with governments willing to engage in terrorism.

NGOs engaged in non-political efforts such as humanitarian aid or human rights promotion, may find themselves targeted by terrorists because they become a threat to the strategies or tactics used by the terrorist group. If the goal of terrorists is to promote a chaotic environment, then those that are engaged in stabilization operations become targets. In the assembled database, 197 terrorist incidents or 44.6 percent of NGOs targeted by terrorists were involved in stability operations. While examples of this type of target selection are legion, a few examples may help to understand this targeting imperative. Three nuns and an American lay volunteer were kidnapped, raped and shot to death in 1980 in El Salvador. They had been working to help feed the poor in the countryside. The brutal rapes and executions could not but send a message to any considering helping the poor in the area to cease and desist (Database). In 1991, Sendero Luminoso guerrillas killed an Italian priest who had been running social programs in Northern Peru (Database). The sole "crime" of this Catholic priest was providing poor Peruvians with access to job training, clean water and limited access to healthcare.

Perhaps the best illustrations of this targeting imperative in action are those attacks that only disrupt the humanitarian activities of NGOs rather than attacking the personnel or property of the NGO specifically. These attacks are especially illustrative in that the attacks were directed at the relief supplies themselves rather than at the workers or their organization. In 1993, the United Revolutionary Front attacked a Red Cross convoy and burned the trucks carrying aid (Database). Similar attacks in Iraq in December of 1992 destroyed 8 UN aid trucks, and implanted bombs were discovered planted in several more (Database). Again, attacks in Ethiopia in 
1985 specifically targeted the trucks carrying food supplies, and in one attack, 24 trucks carrying almost 450 tons of food were burned (Database).

Nor is this tactic unsuccessful. Attacks on aid agencies or humanitarian groups have led to well-known and well respected groups such as the Red Cross, various UN humanitarian agencies, and Action Aid to completely suspend operations and withdraw personnel from the regions or countries in question. Aid organizations suspended operations due to terrorist attacks seven times in the ten-year period from 1985 to 1995. In one case in 1996, attacks against United Nations Children's Fund (UNICEF) in Afghanistan caused a halt to a vaccination campaign (Database).

Clearly, there was some strategic or tactical reason the terrorists targeted the food supply as well as other humanitarian projects. In these cases, it is hypothesized the terrorists were trying to capitalize on the chaos caused by the lack of basic necessities. It can be theorized that the terrorists hoped that this chaos would evolve into either decreased legitimacy for those in power or an increase in power for those who would be able to control the access to food and basic humanitarian needs.

Finally, terrorists may find some actions carried out by NGOs politically unacceptable. A Marxist group, for example, could find entrepreneurial infrastructure building activities politically objectionable, and as such may target NGOs engaged in such activities. This type of targeting can be illustrated by the 1988 incident in Peru, where Sendero Luminoso took control of an isolated village in the Andes. Sendero Luminoso then arrested "lackeys of imperialism and enemies of the revolution" which included a young French man and woman who were working in the village with the Committee for the Development of Agriculture. The young French workers were then executed along with three other villagers by having their throats cut (Database). Another attack occurred in 1991 where Sendero Luminoso attacked a Canadian-financed alpaca-breeding project's vehicles and killed eight people (Database). Sendero Luminoso, a Marxist group opposed to private enterprise, foreign aid and investment, targeted foreign NGOs promoting these things.

Similar attacks have also been carried out by other terrorist organizations. In one case, a Mexican national attached to the International Labor Organization of the UN was kidnapped, beaten and left to die on a roadway in the Guatemalan countryside. She was had been previously threatened due to her work with a group that marketed local crafts. Another Maoist group attacked the Asian Development Bank in Kerala, India in 1992, destroying computers and files (Database). In these cases, NGOs were attacked for activities which were politically contrary to those of the terrorist group. Ironically, attacks have also taken place due to a lack of action. In 1978, the Zimbabwe African Nationalist Union (ZANU) staged an attack in which guerillas shot and killed a German Jesuit priest for not providing a higher education to locals (Database).

\subsection{Competition for Resources}

Returning to the definition of politics, some activities may bring an NGO into the targeting crosshairs based on a third definition of politics: conflict or competition over scarce resources. While this is related to the other definitions of politics, and as such, aspects of terrorist targeting strategies, there are some subtle but important differences. This targeting imperative draws more on the work of Cooley and Ron (2002), which describes the conflict that has emerged among NGOs as they strive for resources in an increasingly scarce marketplace. Cooley and Ron argue that due to the constraints forced on NGOs by a scarce resource marketplace, NGOs may act in ways that are in conflict with their stated mission (Cooley \& Ron, 2002: 5-39).

Granted, terrorist organizations are not typical non-governmental organizations. However, there are certainly aspects of these groups that allow for such a characterization. Again, drawing from Cooley and Ron (2002), it can be theorized that terrorist organizations must also compete for resources in an increasingly competitive marketplace. In the post September 11 world, the major powers have combined to target and remove the financing pipelines that terrorists counted on for support. Further, countries that supported terrorism in the past have frozen that support due to outside pressure. It can thus be theorized that as scarcity increases, so will attacks for resources.

The targeting imperative that causes terrorists to conduct attacks for the purpose of gaining resources may be analogous to Drake's logistical strategy. Indeed, Drake (1998) defines logistical targets as: "Those which are attacked in order to provide or safeguard the group's resources”. Resources can be defined in many different ways. In order for a terrorist group to be successful, it requires many things. Most important are money and weapons. However, like most things, if you have the money, you can get anything else you need. 
In some cases, there may be difficulty in distinguishing between terrorists and organized criminals. Conducting a terrorist campaign can be costly. Further, money is definitely a scarce resource. While an attack solely for the purpose of garnering money is not a political act, and as such, not terrorism, combining an attack in a way that allows a terrorist organization to further one or more of its political goals while still obtaining resources is simple multitasking. The purity of the "politicalness" may be in doubt, but it fits the definition on those grounds. The domestic terror event perpetrated by Timothy McVeigh began with criminal activities intended to procure financing and supplies (U.S. District Court Transcripts, 1997). Without the supplies, the actual attack meant for the broader stage could never have occurred. Again, while many operations meant to obtain financing for an actual attack are not terrorism, some of them may be.

If terrorist groups may select targets based on the ability of the attack on that target to obtain resources, then it stands to reason that terrorist might target NGOs on the basis that the NGO has access to resources that the terrorists want. Kidnappings by the militant Muslim Abu Sayyef Group (ASG) in the Philippines have targeted competing religious groups, driving away heretical or infidel influences. However, they have also tapped into the monetary resources that those religions or the adherents of the religion can access. That these types of attacks also have an associative and political result is simply icing on the cake. To the victim, the differentiation of groups between terrorist and criminal is purely academic; the result is the same. As far as the ASG is concerned, the majority of their attacks entailed kidnapping for ransom. Indeed, 27 incidents or six point one percent of all attacks on NGOs were accompanied by demands for ransom.

Financing for executing operations is not the only resource needed by terrorist groups. For an organization to be successful, groups need safe havens and access to recruits. Often, NGOs are targeted because they put terrorist's access to these resources at risk. How NGOs engaged in humanitarian work might incur the wrath of terrorist groups was described previously. Cragin and Chalk (2003), in their work on how social and economic development can reduce support for terrorists, describe another aspect of terrorist resource scarcity. Terrorist groups thrive in an environment of chaos, lawlessness and poverty. Poor, hopeless, starving people might feel less inclined to support those in power. They, in fact, might be inclined to support terrorists in their attempts at overthrowing the status quo. As a result, terrorists rely on these types of populations for recruits, safe houses (concealment), and other resources. Takeyh and Gvosdev (2002) document the recent movement away from terrorists' reliance on strong state support towards failed states precisely for those reasons. If NGOs are working to eliminate this kind of environment, terrorists might target the NGO in order to protect its lines of supply. Kydd and Walter (2006); and Walsh and Piazza (2010) also theorize that terrorists hope to entice states to overreact after an attack, which will then aid in a future sympathetic audience and recruitment base.

There is evidence that terrorists conduct some operations precisely due to their need for recruits. Alcides Jimenez, a parish priest is Columbia, was killed while saying mass. He had advocated neutrality to his parishioners in the Columbian civil war (Database). In this case, the advocacy of neutrality, or Jimenez telling his people not to support either side, could reduce the likelihood for those parishioners to support the terrorists. Another example is perhaps more illustrative. In 1977, three Jesuit Priests and four Dominican nuns at the Masumi Catholic Mission in Rhodesia (Zimbabwe) were killed when gunmen attacked the mission seeking recruits. The mission was a boarding house for four hundred students. The terrorists took three hundred of the students across the border to Botswana after the attack (Database). Thus it can been seen that if NGOs put resource supply lines at risk, threatening finances, safe havens, or recruitment, those NGOs could find themselves in the crosshairs.

Beyond logistics and recruitment, there is a large literature focused on the foundational issue for the terrorist groups reason for being: That terrorist groups are in competition for influence; whether among supporters, interested watchers, or those they are fighting. Bloom (2005) notes that terrorist groups competing for resources (recruits or control), are more likely to engage in increasingly violent acts (outbidding) to demonstrate their capabilities. Bloom indicates that the end result is an environment where violence has been increased to where civilians and non-governmental groups are targeted and where that violence has become legitimized. The violence is reinforced by the recruits drawn by this kind of violence (Crenshaw, 1985). Just being an innocent in such an environment might make NGOs a target.

\subsection{Social, Religious, or Cultural Conflict}

Another strategy, which helps to explain why terrorists might target NGOs, relates to Easton's (1965) definition of politics, "the authoritative allocation of values for a society". In this case, the terrorist groups desire to control the "authoritative allocation of values" for a given population. In other words, the terrorist groups desire to set 
the agenda for what a population thinks, what they should believe, and how they should live. This type of targeting could be described as the cultural/social/religious imperative.

Cultural/social/religious targeting is especially good at explaining the actions of fundamental terrorist groups. Many of the fundamentalist groups are promoting a value system, and they will brook no dissent or argument when it comes to those values. In the case of fundamentalist terrorists, they desire to control the religious beliefs of a population, which then becomes associated with the structures of government to include interpretations of human rights as well as the judicial structure. Particularly in the case of fundamentalists, any incursion by someone bringing a culture or viewpoint different than that of the fundamentalists could be considered to be a polluting influence. In the case of communities where standards of dress and morality are highly regulated, simply the presence of those living a different standard could be considered to be threatening.

Let us consider the example of the Armed Islamic Group (known by its French acronym GIA), attacks on non-Algerian "polluters" during their campaign to eject all foreign influences from Algeria. From their perspective as fundamentalist Muslims, all foreigners, whether they be non-governmental organizations with personnel from the West, or Western press, not only represented evil, but were evil. The Westerners, by the fact of who they were, brought non-Muslim influences which were antithetical to the GIA. As a result, the GIA then went on to cleanse the rest of the country of those influences: education, music, literature and drama. Westerners listen to popular artists on their stereos; they wear Western clothing that does not cover the body the way clothes should; they promote ideas like equal rights for women, and separation of church and state that go against the fundamentalist interpretations of the Koran. Foreign personnel, even those working for a cause that is nominally acceptable, were polluting their country.

Often, traditional authorities within a society decry the corrupting influence of outsiders. This is especially true of Western outsiders due to the spread of the dominant world culture. This research chooses to call this "cultural imperialism". Often, NGOs are the vehicle by which Western culture is transmitted. This is the case both overtly, through organizational goals and covertly, by means of unconscious messages sent by the personnel themselves. The replacement of traditional food, music, and clothing by those from outside the country are all part of what some societies might term cultural imperialism.

In the end, anything that goes against the accepted conception of the world could pose a threat to groups attempting to authoritatively control the distribution of values in a society. Thus, NGOs that champion human rights may challenge the terrorist' world-view. Groups trying to empower women in areas where fundamentalists wish to limit women's rights may incur the terrorists' ire. There are specific examples of this type of targeting in attacks which were perpetrated on Afghani women in late 2002. In three cases in two months, terrorists targeted Afghani women who were working for international NGOs. Statements left at one site warned all women to abandon working for Western Aid groups (Database). Women who worked for foreign aid groups had subjected themselves to foreign influence and polluted themselves. In those cases, terrorists were willing to take action to halt this kind of cultural pollution.

Terrorist groups can target non-governmental organizations, especially religious non-governmental organizations, if the terrorist groups feel that the NGO is supplanting the religious values that the terrorist groups are espousing. Certainly one aspect of the GIA offensive against the French in Algeria was the "polluting" influence that was encroaching on the religious as well as cultural world-view of Algerians. This targeting imperative is illustrated by the attack by the GIA attack on four Catholic priests killed in their mission in Tizi-Ouzou. In claiming credit for the attack, the GIA stated the attack was part of their campaign of "annihilation and physical liquidation of Christian crusaders” (Database). In 1994 alone, 74 foreigners were killed.

This phenomenon is not unique to Algeria. The Sudan People's Liberation Army (SPLA) has attacked Catholic missionaries and nuns charging them with "spreading Christianity" (Database). Attacks in 1992 in Afghanistan and 1994 in Somalia also targeted Christian NGOs on the basis that they either were infidels or were polluting holy land or that the NGOs promoted Christianity (Database).

Formal religion aside, terrorist might target anyone challenging their social or cultural views. Indeed, the GIA targeted anyone that deviated from their version of proper thought. Drake (1998: 52) documents the murder of feminists, educators, entertainers and writers. The GIA was especially concerned with the role education played in forming the worldview of students in Algeria. Again, Drake documents "over eighty teachers were killed and 600 schools had been attacked... three universities and nine training institutes were burned... three heads of Algerian universities and over fifty academics were killed". This phenomenon is also evident in recent events in Iraq. Nancy A. Youssef documented recent attacks on hair salons, music stores, in short, anything that the fun- 
damentalists considered to be inappropriate under their version of correct thought and action (Youssef, 2004).

Beyond traditional values, the prevalence of Northern NGOs engaged in work in the global South has led some to question the motives of the Northern NGOs. Skjelsbaek (1971) describes this phenomenon when third world countries feel pressures to adapt to Northern influence. Indeed, he labels the phenomenon "neo-colonialism". Certainly, groups in the global South might feel the need to resort to violence to protect their way of life. The NGO database records 73 incidents or 16.5 percent of all attacks on NGOs, which can be attributed to attacks on the culture, religion or society that the attacked NGOs represent.

\subsection{Soft Targets}

The final reason why terrorist might target non-governmental organizations is the reason that Hoffman (2001) noted when discussing this topic: it has to do with the relative ease of carrying out an attack and the security environment within which the NGOs and terrorists reside. Drake (1998: 179) theorizes that, "where there is a number of potential targets, attacking any of which would yield a roughly equivalent strategic benefit, there is a likelihood that the terrorists will choose to attack the softest target, as carrying out such an attack represents the least risk to the terrorists".

It must be conceded that suicide attacks do not fit this assertion. However, in terms of likely targets, even suicide attacks choose targets that will allow the greatest opportunity for destruction. While hardened targets would allow for the perpetrators of the attack to carry out one of their goals, namely suicide, the more important of the goals would not be abetted by a hardened target. Thus, even those not concerned about personal risk will pursue softer targets. Suicide attacks also fit in the costly signaling and outbidding arguments posited previously.

Recent anti-terrorism programs have served to "harden" or increase the difficulty of successfully carrying out an attack. Hoffman describes the recent security environment as being a much more difficult place for terrorists to target indiscriminately. This shift is recognized by terrorists and academics alike. He notes that while the primary target of terrorists had been government officials and installations, as security increased and protective measures were engaged, terrorists began to shift targets (2006). Enders and Sandler $(1993,2004)$ find that when targets are hardened, terrorist groups substitute tactics such as suicide attacks and or target selection to softer targets to increase the probability of success of the attack. Brandt and Sandler (2010) find that over the recent 40 year period starting in 1968, terrorist groups have increasingly targeted businesses and nongovernment groups rather than military and government targets as they have been increasingly hardened.

The shifting of targeting from hardened targets to softer targets may be abetted by NGOs themselves. Given the mission of most NGOs, taking measures to reduce the exposure to terrorism may be counter-productive to their goals. Religious non-governmental organizations may feel it necessary to welcome all-comers to organizations and facilities. Humanitarian groups may need to be working away from cities with the poor and suffering.

The end result is that many of these organizations find typically prudent security measures hard to adopt. Martin notes that for many NGOs there is, "a conspicuous lack of security among many NGO workers combined with a skeptical, if not averse attitude towards the need for security and other protective measures". Added to this, is the fact that given the nature of the missions for many of these groups, they conduct their work in places that are generally more dangerous and thus, present more of an opportunity for attack. Again, Martin notes that in many of these locations, there is, "a general absence of rules of war or rules of conduct among the belligerents themselves, many of whom are irregular fighters and may also include criminals and bandits interested as much in plunder as in the realization of a particular political agenda” (Martin, 1999).

\section{Conclusion}

It has been shown that the permutations of target selection carry factors from ideology to tactics. Drake delineated a selection process by which terrorists start at all possible attack permutations and then refine and limit the target through ideological, strategic, and tactical inputs. In the end, target selection is a process with many inputs, and the final selection may simply be the easiest target to attack out of many possible.

Terrorism is a fundamentally political phenomenon. Due to the many selection inputs, non-governmental organizations can enter the target selection environment of terrorists. They can be targeted based on a perceived association with a government or intergovernmental entity. NGOs can be targeted due to political activities in which they are engaged. It must be emphasized that any activity, overtly political or not, can have political ramifications, and as such, can provide the political motivation for a terrorist attack. Hence humanitarian aid or infrastructure building has the potential of affecting the political environment of a given area. These too, then, 
could be considered political activities. Terrorists could target NGOs based on a perceived threat to the social, cultural or religious environment considered important to the terrorist group. Terrorists could target NGOs based on the fundamental scarcity of resources in the environment in which the terrorists operate. NGO activities that put the resources of safe haven and an ample recruit pool at risk could put NGOs in danger of terrorist attack. The scarcity of financing to terrorist groups might also lead terrorists to attack NGOs as a means of securing money and resources. Finally, the apparent "softness" of NGOs in terms of ease of attack might lead terrorists to attack non-governmental groups.

Certainly the targeting imperatives are not equal in priority. Neither are they considered independently of each other, for an attack will ideally accomplish more than one goal at the same time. They are also not necessarily considered at the same point in the target determination process. Often they are considered as the refinement process ensues. Again, in the targeting process, refinements are continually being made. As such, one or more of the NGO targeting imperatives might move back or forth along the targeting timeline.

Based on the limited information in the database, dichotomous indicators were created for attacks in the database in which a ransom demand was made. It is theorized that in these cases, the terrorist group is engaged in activities designed to obtain scarce resources. An additional dummy variable was created for an attack in which the terrorist group left evidence which indicated they were targeting the NGO based on an association with another country or governmental entity. In this case the evidence was usually statements in which the groups themselves explained the attacks were against a government entity that they associated the targeted NGO with. Dummy variables were also created for attacks on groups engaged in stabilization operations (humanitarian aid/ infrastructure building) as well as groups engaged in overtly political activities. While there may certainly be coder bias as to what indeed meets the criteria for overt political activities or any other of the dummy variables, in most cases coding was relatively easy. If an NGO representative was actively protesting a government policy - that case was considered political activity. Some of the cases could have been interpreted many ways.

The author attempted to be conservative and did not attribute motive that did not seem clearly evident. This is especially true for the associative variable. Only cases where the terrorist groups left an indication towards motive were cases included. In some cases, the data entry had more than one dummy indicating influence. In those cases, a blended category was created. The theoretic framework lent itself to these dummy variables. However, the targeting imperative dealing with the relative softness of a target could not be accounted for. Despite this fact the framework accounted for 81 percent of all attacks on non-governmental groups. If this is the targeting rubric used by terrorist groups when refining their targeting selections, then perhaps measures can be taken which would lessen the threat to these non-governmental groups.

In the introduction, the author explained the selection of non-governmental organizations as the sample for the creation of the targeting framework. As noted above, the framework seems successful in describing the targeting parameters terrorist groups might be constrained by when selecting NGOs as targets. No one has explored this phenomenon. It seems plausible that there are congruent points with other possible terrorist targets.

\section{Acknowledgements}

Publication of this article was funded in part by the Kansas State University Open Access Publishing Fund.

\section{References}

Abrahms, M. (2008). What Terrorists Really Want: Terrorist Motives and Counterterrorism Strategy. International Security, 32, 78-105. http://dx.doi.org/10.1162/isec.2008.32.4.78

Berryman, P. (1994). Stubborn Hope: Religion, Politics and Revolution in Central America. Maryknoll, NY: Orbis Books.

Bloom, M. (2005). Dying to Kill: The Allure of Suicide Terror. New York: Columbia University Press.

Brandt, P. T., \& Sandler, T. (2010). What Do Transnational Terrorists Target? Has It Changed? Are We Safer? Journal of Conflict Resolution, 54, 214-236. http://dx.doi.org/10.1177/0022002709355437

Claiber, J. (1998). The Church, Dictatorships, and Democracy in Latin America. Maryknoll, NY: Orbis Books.

Cooley, A., \& Ron, J. (2002). The NGO Scramble: Organizational Insecurity and the Political Economy of Transnational Action. International Security, 27, 5-39. http://dx.doi.org/10.1162/016228802320231217

Cragin, K., \& Chalk, P. (2003). Terrorism and Development: Using Social and Economic Development to Inhibit a Resurgence of Terrorism. Santa Monica, CA: Rand Corporation.

Crenshaw, M. (1985). An Organizational Approach to the Analysis of Political Terrorism. Orbis, 29, 465-489. 
Drake, C. J. M. (1998). Terrorists’ Target Selection. New York: St. Marten’s Press.

Easton, D. (1965). A Framework for Political Analysis. Englewood Cliffs: Prentice Hall.

Edwards, M., \& Hulme, D. (1996). Beyond the Magic Bullet: NGO Performance and Accountability in the Post-Cold War World. West Hartford, CT: Kumarian Press.

Enders, W., \& Sandler, T. (1993). The Effectiveness of Anti-Terrorism Policies: Vector-Autoregression-Intervention Analysis. American Political Science Review, 87, 829-844. http://dx.doi.org/10.2307/2938817

Enders, W., \& Sandler, T. (2004). What Do We Know about the Substitution Effect in Transnational Terrorism? In A. Silke (Ed.), Research on Terrorism: Trends, Achievements and Failures (pp. 119-137). London: Frank Cass. http://dx.doi.org/10.4324/9780203500972.ch7

Hoffman, B. (2001). Protecting American Interests Abroad: US Citizens, Businesses and Non-Governmental Organizations. Testimony to the Subcommittee on National Security, Veterans Affairs and International Relations, House Committee on Government Reform. Santa Monica: Rand Publication.

Hoffman, B. (2006). Inside Terrorism. New York: Columbia University Press.

Jenkins, B. (1981). The Study of Terrorism: Definitional Problems. Santa Monica, CA: RAND Publication.

Kydd, A. H., \& Walter, B. F. (2006). The Strategies of Terrorism. International Security, 31, 49-80. http://dx.doi.org/10.1162/isec.2006.31.1.49

Laqueur, W. (2001). A History of Terrorism. Brunswick, NJ: Transaction Publishers.

Laswell, H. (1936). Politics: Who Gets What, When and How. New York: McGraw Hill.

Lipset, S. M. (1959). Some Social Requisites of Democracy: Economic Development and Political Legitimacy. American Political Science Review, 53, 69-105. http://dx.doi.org/10.2307/1951731

Martin, R. (1999). NGO Field Security. Forced Migration Review, 4, 5-7. http://www.fmreview.org/FMRpdfs/FMR04/fmr401.pdf

Marx, K. (1978). Contribution to the Critique of Hegel's Philosophy of Right: Introduction. In R. C. Tucker (Ed.), Marx/Engles Reader (pp. 53-54). New York: W. W. Norton and Company.

Murdie, A., \& Stapley, C. S. (2014). Why Target the “Good Guys”? The Determinants of Terrorism against NGOs. International Interactions, 40, 79-102. http://dx.doi.org/10.1080/03050629.2013.863192

National Consortium for the Study of Terrorism and Responses to Terrorism. Global Terrorism Database. http://www.start.umd.edu/gtd/

Ofreneo, R. P. (1987). The Catholic Church in Philippine Politics. Journal of Contemporary Asia, 17, 320-338.

Shaffert, R. W. (1992). Media Coverage arrd Political Terrorists: A Qzrantitative Analysis. New York: Praeger Publishers, 44.

Skjelsbaek, K. (1971). The Growth of International Nongovernmental Organization in the Twentieth Century. International Organization, 25, 420-442. http://dx.doi.org/10.1017/S0020818300026230

Takeyh, R., \& Gvosdev, N. (2002). Do Terrorist Networks Need a Home? The Washington Quarterly, 25, 97-108. http://dx.doi.org/10.1162/01636600260046262

Tryggestad, E. (2001). Missionaries More Conscious of Being Americans Abroad. The Christian Chronicle, October 22.

United States District Court for the District of Colorado. United States versus Terry Lynn Nichols. Court Transcripts. http://newsok.com/okc-bombing-trial-transcript-12151997-afternoon-2014-cdtcst/article/1075003

Walsh, J. I., \& Piazza, J. A. (2010). Why Respecting Physical Integrity Rights Reduces Terrorism. Comparative Political Studies, 43, 551-577. http://dx.doi.org/10.1177/0010414009356176

Youssef, N. A. (2004). Beauty Salons under Attack in Iraq. Knight Ridder Newspapers, September 9, Washington Bureau. 
Scientific Research Publishing (SCIRP) is one of the largest Open Access journal publishers. It is currently publishing more than 200 open access, online, peer-reviewed journals covering a wide range of academic disciplines. SCIRP serves the worldwide academic communities and contributes to the progress and application of science with its publication.

Other selected journals from SCIRP are listed as below. Submit your manuscript to us via either submit@scirp.org or Online Submission Portal.
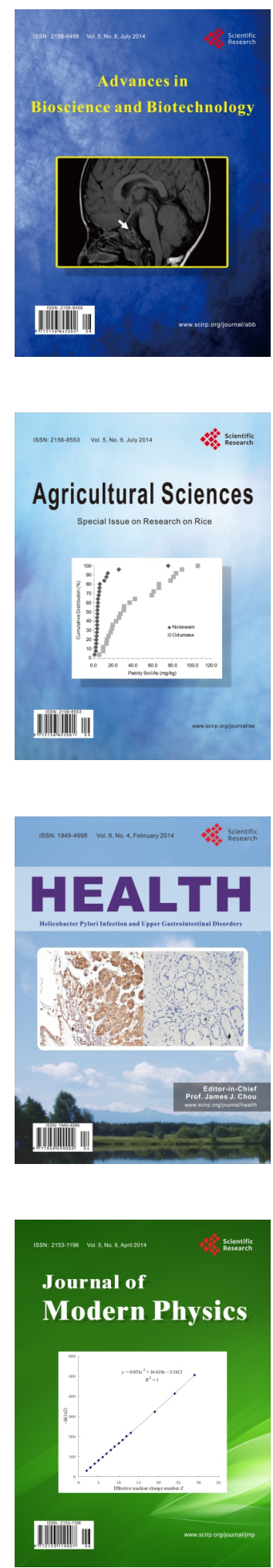
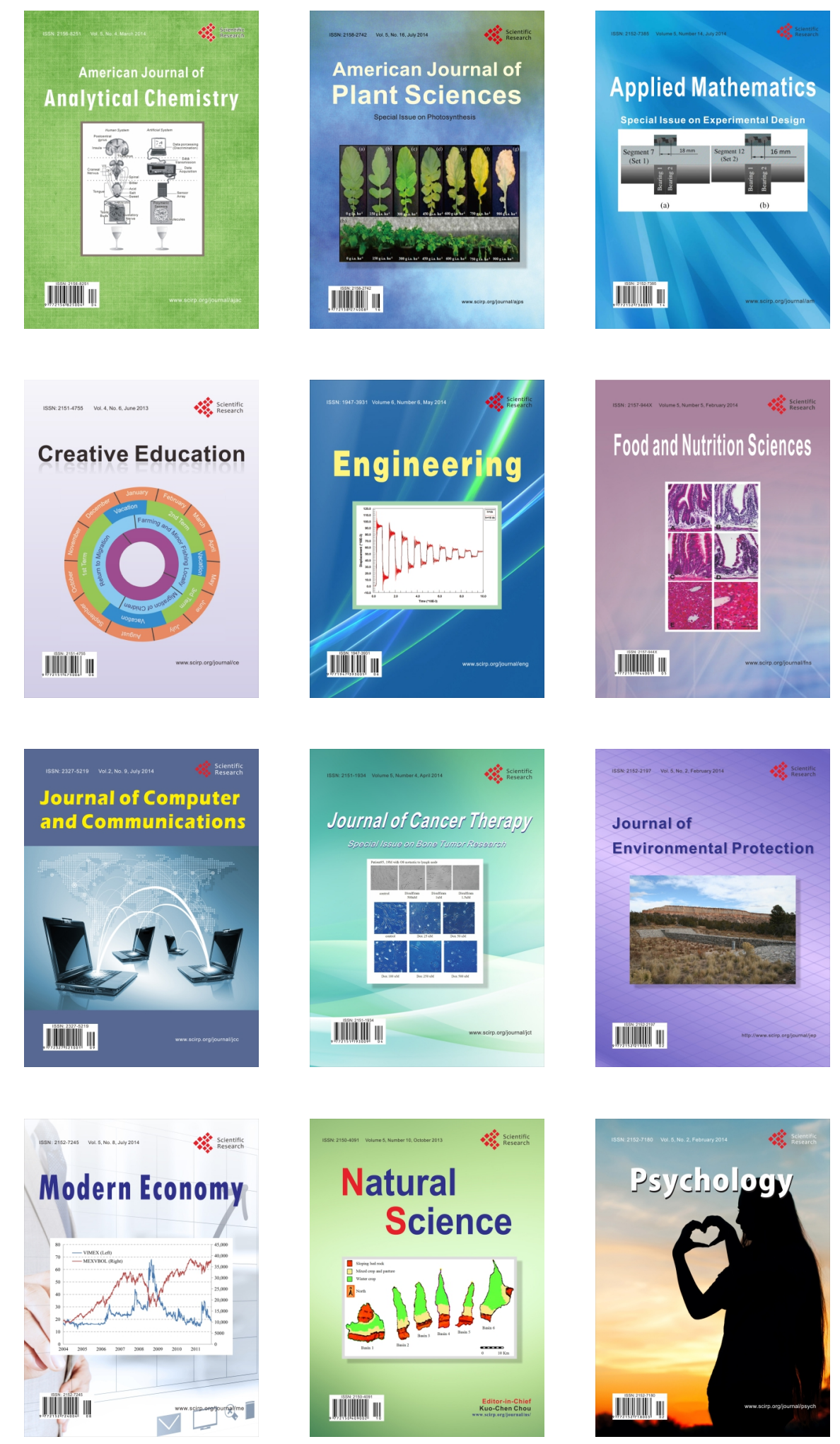